\title{
The Karoo: The Burlington House
}

Let's go down the footpath to the fields of wild tobacco where October blossoms after a rainstorm of white descent, whirl through the dust to become nothing. Among the yellow firethorn the young beetles cavort, and in an intensity of purple see the quiver of a saffron-shaded butterfly's wing.

Perhaps we'll go where the river runs parallel with the sea, to the dune forest where the pine fallings drift down to settle on damp sand ... No ... inland, an overlay of hills hides a corrugated iron house with an interior of glass, mirrors, and coral coloured ribbons.

There great winds blast through the windows, lifting the dust into chaos.

When the coal fire flares,

a discharge of heat scatters the ash, and like down it floats onto a cold stone floor. (There the ceilings are so high.) A still chamber reveals a glass doll, the crystal eyes stare lifelessly ahead. Iridescent light pools at the corners, then slides over her cheeks like fallen tears. (There the lace handkerchiefs are so old ...) The lure of the sash window entices the moon to steal noiselessly as a phantom onto its sill, and to slip through its opening to spread a white mantle over ancient marble.

Garlands of berries and bell flowers, are entwined in carved wooden ribbons against a mahogany cabinet. From above, pale wax drops from the hearts of rose candles.

On a white-tiered plate with personalized napkins, pink, yellow, and blue petit-fours glazed with apricot, lemon fondant, marzipan, and vanilla are crowned with cherries and frosted roses. The 'treat me', 'kiss me', 'love me', 'hug me' biscuits lie undetected beneath candy kisses, gingerbread-hearts and iced flowers.

You rest on a four-poster bed, your damp hair upon the faded, cotton cushions, and sheets with frayed hems.

At the corners our initials unravel ... (and the scent of Marigolds is in the air). Like a child trapped in a closet, hidden love hungers between the halves of a sealed locket on your breast.

But then ... your urgent whisper ... (stilled by my cold finger pressed to your lips). I draw up the covers and turn away ... and the wind that drifts across the plain is like your warm breath mingling with my own, and detained in each stroke of the windmill, is your suggestion ... and it lingers on the edges of my mind like a negligently placed visiting card ...

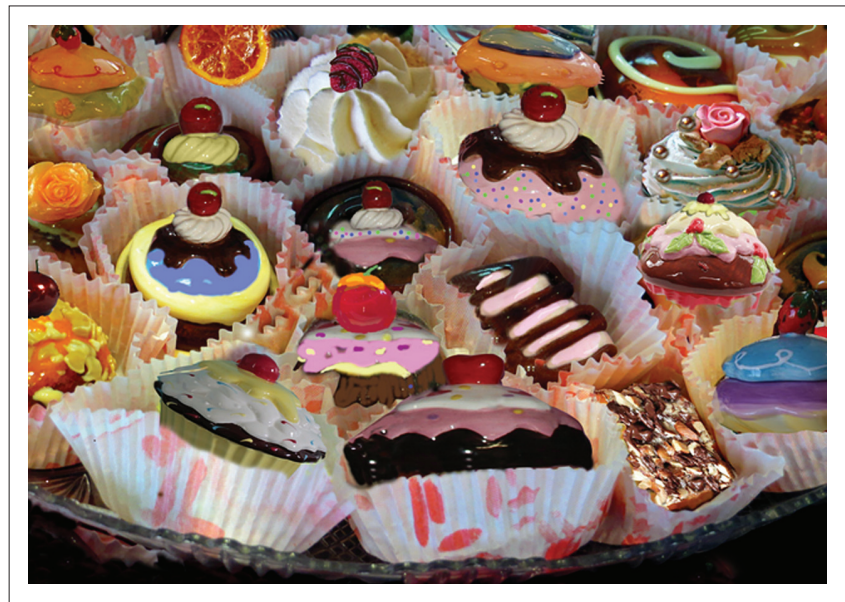

Source: This picture is used with the permission of the author and photographer, Patricia G. Maritz

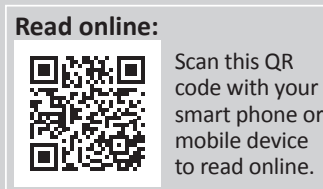

Author: Patricia G. Maritz ${ }^{1}$

Affiliation: ${ }^{1}$ Department of Philosophy, University of Zululand, South Africa

Corresponding author: Patricia Maritz, patricia.maritz@gmail.com

How to cite this article: Maritz, P.G., 2017, 'The Karoo: The Burlington House', Literator 38(1), a1265. https://doi.org/10.4102/ lit.v38i1.1265

Copyright: (C) 2017. The Authors. Licensee: AOSIS. This work is licensed under the Creative Commons Attribution License. 